\title{
Toxicity assessment of the alcoholic leaves extract of Reinwardtia indica
}

\author{
Prabhat Upadhyay, Rashmi Shukla², Kavindra Nath Tiwari ${ }^{3}$, G P Dubey ${ }^{4}$, Sunil Kumar Mishra $^{5 *}$ \\ ${ }^{1}$ Department of Pharmacology, Institute of Medical Sciences, Banaras Hindu University, Varanasi, India, ${ }^{2}$ Department of \\ Medicinal Chemistry, Institute of Medical Sciences, Banaras Hindu University, Varanasi, India, ${ }^{3}$ Department of Botany, \\ MMV Banaras Hindu University Varanasi, India, ${ }^{4}$ Institute of Medical Sciences, Banaras Hindu University, Varanasi, India, \\ ${ }^{5}$ Department of Pharmaceutical, Engineering and Technology, Indian Institute of Technology, Banaras Hindu University,
} Varanasi, India

\begin{abstract}
The present study aimed to evaluate the safety of the alcoholic leaves extract of Reinwardtia indica in Charles foster rats through an acute and sub-acute oral administration.For assessment of acute oral toxicity test, ratswere orally treated with single dose of the alcoholic leaves extract of Reinwardtia indica at the doses of 50, 250, 500, 10002000 and $5000 \mathrm{mg} / \mathrm{kg}$. In sub-acute toxicity study, using the OECD guidelines no. 407, the extract was administered at the doses of $50,250,500,1000,2000 \mathrm{mg} / \mathrm{kg} / \mathrm{day}$ for 28 consecutive days and at the dose of $2000 \mathrm{mg} / \mathrm{kg}$ satellite group also used for 6 weeks.In acute toxicity above mentioned doses neither showed mortality nor exterior signs of toxicity. In sub-acute, study no significant changes found in haematological and biochemical level ofthe treated rat after 14 days and 28 days in comparison to control. The histopathology of rat brain, kidney, liver, and heart also showed the no cellular changes after extract treated rat.The alcoholic leaves extract of Reinwardtia indica was found non-toxic in single drug dose administration up to $5000 \mathrm{mg} / \mathrm{kg}$ (acute study) and in sub-acute administration up to $2000 \mathrm{mg} / \mathrm{kg}$.
\end{abstract}

Keywords:Reinwardtia indica.Biochemical test.Hematological test.Histopathology.

\section{INTRODUCTION}

Reinwardtia indica Dumort is commonly known as Pyoli, Basanti, phunili, shivali etc.It belongs to the Linaceaefamily and found in the Himalayan region of India, Nepal, and China and the Western Ghats. Only three species of Reinwardtia, are known which are native to Southern Asia namely Reinwardtia indica (Rawat et al., 2015), Reinwardtia trigyna (Perveen, Qaiser, 2008) and Reinwardtia sinensis (Quanru, Zhou, 1998). In India, the genus is represented by only one species i.e.R. indica, native of Himalayan foothills found in a wide altitudinal range of 500-2500 masl. It is used as folk medicine in India;traditionally people used the plant for the treatment of boils, pimples, skin infection and carbuncle. The bright yellow petals of the plant were used for tongue wash whereas the crushed leaves were used to treat paralysis as its chemical component would act upon the sodium pump. The stem paste was used as wound healer in cattle's

\footnotetext{
*Correspondence: S. K. Mishra. Department of Pharmaceutical Engineering and Technology, Indian Institute of Technology, Banaras Hindu University, Varanasi U.P. India-221005. E mail: skmishra.phe@itbhu.ac.in
}

when affected by maggots (Pande, Tiwari, Pandel, 2007). The plant is also used to increase the lactation period and its flower is used as a dye for clothes. The paste of the whole plant is used to get relief from backaches (Malla, Gauchan, Chhetri, 2014; Sidhu, Thakur, 2016). It is used in traditional Chinese medicine formulation for the treatment of acute or chronic gastritis (Cn, 2014a; 2014b). Reinwardtia trigyna is used as natural herbicide and weedicide as it showed a good phytotoxic activity (Khan et al., 1998; Perveen, Qaiser, 2008; Abha, Swati, Shukla, 2013). The reported pharmacological activity of the other plants belong to the same family (flax family) are used as antioxidant, wound healing, anti-microbial, anti-inflammatory, and anti-nociceptive agent. Medicinal properties of the plant are due to the presence of alkaloids, flavonoids, phenolic, tannins and other phytoconstituents. Several reports have demonstrated that secondary plant metabolites exert diverse medicinal biological effects (Saleem et al., 2005). In ultra-performance liquid chromatography mass-spectrometry (UPLCMS-MS) of the extract showed several essential phyto-molecules belongs to flavonoid class, reported in the treatment and 
management of lifestyle related disease or disorders like, neurodegenerative, anti-depressant, cancer, anti-diabetic, metabolic disorders etc. (manuscript submitted). The aim of this study was to assess the acute and sub-acute toxicity study in Charles foster rats at different dose level with haematological and biochemical estimation from blood and histopathology of brain, kidney, heart \& liver after 14 th $\& 28$ th days.

\section{MATERIAL AND METHODS}

\section{Plant material and preparation of extracts}

$R$. indica was collected from Uttrakhand (2000$2200 \mathrm{~m}$ altitude) the surroundings of the region of the Himalayan in the month of September to February. Plants were flowering in winter (Paudel Chhetri et al., 2008; Bhat, Kumar, Bussmann, 2013). The specimen of plant part leaves and stem were identified at the Herbarium (Voucher specimen number Lina.2015/1) of the Department of Botany, Institute of Science by Professor N. K. Dubey. Leaves were washed thoroughly under running tap water, oven dried at $50-60^{\circ} \mathrm{C}$ for two days finely ground using an electric blender and stored in plastic containers at room temperature and in darkness until required for use. For the preparation of extract, the powdered sample of leaves (100 g) were extracted by using a Soxhletapparatus with hot percolationmethodand absolute ethanol $(250 \mathrm{ml})$ was used as a solvent. The extract was then filtered and evaporated to dryness at a $45^{\circ} \mathrm{C}$ with a rotary evaporator (Buchi R-210 Advanced, Switzerland) and named as AERI.

\section{Experimental design}

\section{Animals}

The protocol of this study was approved by Institutional Animal Ethical Committee of Institute of Medical Sciences (BHU Varanasi, India). The inbreed albino female rats of Charles foster strain (120-150 g) was purchased from the Central Animal Facility of our Institute and acclimatized in our laboratory conditions for 7 days with free access to normal standard chow diet and tap water. They were maintained under standard conditions of temperature $\left(23 \pm 2^{\circ} \mathrm{C}\right)$ and a relative humidity of $50 \%$.

\section{Acute toxicity}

The oral acute toxicity study was carried out according to the guideline Nr. 423 provided by the Organization of Economic Cooperation and Development (OECD) for the acute toxicity class method (ATC) procedure with slight modifications. Prior to administration of treatment, animals were weighed, marked and fasted overnight without suppression of water. Animals of the control group received distilled water whereas the treated groups received a single dose of 50, 250, 500, 1000, 2000 and $5000 \mathrm{mg} / \mathrm{kg}$ body weight of the alcoholic extract of Reinwardtia indica leaves (AERI) freshly prepared. After dosing, food was with held for a further 3-4 h while animals were observed individually for clinical signs of toxicity such as mortality, respiratory pattern, changes in general behaviour, skin, eyes, fur and somatomotor activity.

\section{Sub-acute toxicity study}

According to the OECD guidelines no. 407 with slight modification, rats were divided into 6 groups of 6 animals and treated by gavage. Control group received distilled water while, the AERI treated groups received the extract once daily $(10: 00-1: 00 \mathrm{pm})$ for 28 consecutive days at the doses of 50, 250, 500, 1000 and $2000 \mathrm{mg} / \mathrm{kg}$. Satellite group at the dose of $2000 \mathrm{mg} / \mathrm{kg}$ also used for 6weeks to observe the effect of extract in animals.

\section{Body weight, food and water consumption}

Body weights of the rat in all groups were recorded before administration of doses, further body weight was taken weekly entire treatment and finally on the day of sacrifice. The amount of food and water intake was recorded daily. The consumed amount of food and water were measured before provide to each group, their remnants were calculated next day to get the differences, which were recorded as daily food (gm./rat/day) and water consumption ( $\mathrm{ml} / \mathrm{rat} /$ day).

\section{Blood analysis}

Blood samples were collected from the retro-orbital region of the rats for measurement of haematological (EDTA-coated tubes) and biochemical (dry tubes) parameters after 14 days and 28 days.

\section{Hematological analysis}

The blood samples collected in heparinized tubes were used for the hematological analyses. The following parameters: red blood cell count (RBC), white blood cell count (WBC), neutrophils (NP), lymphocytes (LC), monocytes (MC), eosinophils (EP), hemoglobin $(\mathrm{Hb})$, platelets $(\mathrm{PL})$ and packed cell volume (PCV) by automated analyzer (KX-21-Hematology-analyzer, SysmexCorporation, USA). 


\section{Biochemical analysis}

Dry tubes containing collected blood were centrifuged at $3000 \mathrm{rpm}$ at $25^{\circ} \mathrm{C}$ for $15 \mathrm{~min}$ to obtain the serum, which was stored at $-20^{\circ} \mathrm{C}$ until the measurement of biochemical parameters (Erbachem 5 semi-auto analyzer). Serum glutamic oxaloacetic transaminase (SGOT), Serum glutamic pyruvic transaminase (SGPT) (Coral clinical system), Alkaline phosphatase (ALP) (Arkray health care Pvt. ltd.), Urea, Creatinine (Coral clinical system) and BUN.

\section{Histological analysis}

Organs such as heart, liver, kidneys, and brain were excised and fixed in 10\% formaldehyde for histological analysis. Paraffin-embedded organs were cut into $5 \mathrm{~mm}$ sections and stained with hematoxylin and eosin. Stained sections were visualized and all measurements performed using a Nikon eclipse e200 microscope equipped with cat cam 300-3.0MP micro cope cameraconnected to a computer where the images were transferred and analyzed with the Scope Tek scope photo x86, 3.1.475.

\section{Dose estimation}

The toxicity study was performed according to OECD guideline 407 and 423 up to $5000 \mathrm{mg} / \mathrm{kg}$ for acute and in sub-acute $2000 \mathrm{mg} / \mathrm{kg}$ body wt. of the extract. Extract showed no significant toxicity in physiology, biochemical and histopathology of the animal. For in vivo biological activity the estimated dose for animals may be $1 / 10$ th or $1 / 20$ th of maximum dose from toxicity assessment study. The human daily dose is estimated by body surface conversion and using the formula:

Human equivalent dose $(\mathrm{HED})=$ Animal dose $(\mathrm{mg} / \mathrm{kg})$ X Animal $\mathrm{Km} /$ Human $\mathrm{Km}$

\section{Statistical analysis}

Data are expressed as mean \pm standard error of the mean (SEM). Comparison and analysis were performed using the one way ANOVA one way variance followed by Dunnett's multiple comparisons. The $\mathrm{p}$ values $<0.001$ were considered as significant.

\section{RESULTS AND DISCUSSION}

Before pharmacological study of any medicinal plant, the acute and sub-acute toxicity is the mandatory requirement as per the standard guideline and to develop the phytopharmaceutical product (Parasuraman, 2011). It is also the process of dose determination at the pre-clinical level in drug discovery and development process (Zhang et al., 2012). Reinwardtia indica is the novel medicinal plant used as a folk medicine in the treatment and management of several diseases on the basis of traditional uses but no scientific report available till today. First, we standardized the plant materials, evaluated the anti-oxidant, antimicrobial activity and profiling the phytochemical through UPLCMS-MS (paper submitted), further assess the acute and sub-acute studies in animal first time.

\section{Acute toxicological evaluation}

To assess the acute toxicity of AERI, female rats were orally treated single days with various concentrations (50, $250,500,1000,2000$ and $5000 \mathrm{mg} / \mathrm{kg}$ ) of AERI for one day. Mortality, clinical signs, temperature, change in skin, eye colour change, food intake, general physique, diarrhoea, sedation were recorded. There were no treatment-related mortalities in any groups. Additionally, none of the rats treated with single days AERI displayed remarkable changes in clinical observations during study period however at higher doses $(2000 \mathrm{mg} / \mathrm{kg} \& 5000 \mathrm{mg} / \mathrm{kg})$ animals were showed the sedation (Table I).

\section{Sub-acute toxicity}

Specifically assess the sub-acute toxicity rats were sorted into six groups and treated with control 50, 250, $500,1000,2000 \mathrm{mg} / \mathrm{kg} /$ day for 4 weeks and satellite dose $2000 \mathrm{mg} / \mathrm{kg} /$ day for 6 weeks. Body weight, intake of food \& water, hematology, serum chemistry and microscopic findings were recorded after 2 weeks and 4 weeks. In satellite treated group, the intake of food,water consumption, hematology and biochemical were assessed after 6 weeks.

\section{Effect of AERI on body weight, food intake and water consumption in rats}

After 28 days of oral administration, the food intake and water consumption were also not affected.It indicates that the extract did not induce appetite suppression and deleterious effects on growth of rats. Normal health of rats suggested that no significant changes were observed in their physiological as well as metabolic activity. However, in some sub-acute studies of the extract, these changes were observed due to the extract treatment at several doses which influenced the food and water intake of rat. The negative effect of the extract showed at the particular 
TABLE I - Behavioral responses and general appearance of rat treated with single dose of AERI in acute toxicity study

\begin{tabular}{|c|c|c|c|c|c|c|c|}
\hline Observation & Control group & $50 \mathrm{mg} / \mathrm{kg}$ & $250 \mathrm{mg} / \mathrm{kg}$ & $500 \mathrm{mg} / \mathrm{kg}$ & $1000 \mathrm{mg} / \mathrm{kg}$ & $2000 \mathrm{mg} / \mathrm{kg}$ & $5000 \mathrm{mg} / \mathrm{kg}$ \\
\hline Temperature & Normal & Normal & Normal & Normal & Normal & Normal & Normal \\
\hline Change in skin & No effect & No effect & No effect & No effect & No effect & No effect & No effect \\
\hline $\begin{array}{l}\text { Eye color } \\
\text { change }\end{array}$ & No effect & No effect & No effect & No effect & No effect & No effect & No effect \\
\hline Food intake & Normal & Normal & Normal & Normal & Normal & Normal & Normal \\
\hline $\begin{array}{l}\text { General } \\
\text { physique }\end{array}$ & Normal & Normal & Normal & Normal & Normal & Normal & Normal \\
\hline Diarrhea & Not present & Not present & Not present & Not present & Not present & Not present & Not present \\
\hline Coma & Not present & Not present & Not present & Not present & Not present & Not present & Not present \\
\hline Drowsiness & Not present & Not present & Not present & Not present & Not present & Not present & Not present \\
\hline $\begin{array}{l}\text { Breathing } \\
\text { difficulty }\end{array}$ & not observed & not observed & not observed & not observed & not observed & not observed & not observed \\
\hline Sedation & No effect & No effect & No effect & No effect & No effect & Observed & Observed \\
\hline Tremor & Not present & Not present & Not present & Not present & Not present & Not present & Not present \\
\hline Death & Alive & Alive & Alive & Alive & Alive & Alive & Alive \\
\hline
\end{tabular}

dose toxicity in rat (Koumba Madingou et al., 2016). But during dosing (28-day) and the recovery periods, there was no significant change in food and water intake $i$ at different dose treated groups as compared to their respective control (Table II). In satellite group, also rat treated with the highest dose $(2000 \mathrm{mg} / \mathrm{kg} \mathrm{b}$. wt.) did not show any significant change in food uptake and water intake.

\section{Effect of AERI on haematological parameters}

The study of haematological parameters indicates the toxic effects of the extract on the blood of rats due to changes in physiological or pathological level. Blood is

TABLE II - Effect of AERI on food intake and water consumption by rat during 28 days treatment and recovery period (satellite group)

\begin{tabular}{lcc}
\hline Treatment & $\begin{array}{c}\text { Average food } \\
\text { intake } \\
\text { (g/da/rat) }\end{array}$ & $\begin{array}{c}\text { Average water } \\
\text { intake } \\
\text { (mL/day/rat }\end{array}$ \\
\hline Control & $4.29 \pm 1.90$ & $4.81 \pm 1.20$ \\
$50 \mathrm{mg} / \mathrm{kg}$ & $4.52 \pm 1.61$ & $3.81 \pm 1.94$ \\
$250 \mathrm{mg} / \mathrm{kg}$ & $4.89 \pm 1.31$ & $4.26 \pm 1.92$ \\
$500 \mathrm{mg} / \mathrm{kg}$ & $3.28 \pm 1.02$ & $4.26 \pm 1.68$ \\
$1000 \mathrm{mg} / \mathrm{kg}$ & $4.24 \pm 1.08$ & $4.65 \pm 1.32$ \\
$2000 \mathrm{mg} / \mathrm{kg}$ & $4.39 \pm 1.94$ & $4.83 \pm 1.53$ \\
Satellite control & $4.23 \pm 1.56$ & $4.12 \pm 1.81$ \\
Satellite $(2000 \mathrm{mg} / \mathrm{kg})$ & $4.45 \pm 1.71$ & $4.91 \pm 1.01$ \\
\hline
\end{tabular}

the essential medium for transport of nutrients and foreign bodies in the body. If extract shows the toxicity in the body, it directly affects its components such as red blood cells, white blood cells, platelets and haemoglobin. The ranges of these components either decrease or increase significantly from normal.It indicated that the toxicity caused by the extract which can also affect the body immune as well function of organs (Uddin et al., 2014). Data of haematological analysis of $14^{\text {th }}$ and $28^{\text {th }}$ days were given in Table III and Table IV. Results revealed that no significant changes have been shown in the haematological analysis when compared with control. The same result also found in the satellite treated group.

\section{Effect of AERI on biochemical parameters}

The body has two essential and vital organs for proper function are liver and kidney. The function of liver and kidney are different one is used for metabolism of intake and other one is used for excretion of waste product. To assess the toxicity of any new compound it is necessary to know the status of these two vital organs, which can be checked through biochemical estimation without sacrifice the rat. For liver function assessment mainly used the SGOT, SGPT and ALP however for kidney function assessments mainly used urea and creatinine. After intake of any compound or molecules if any changes have been seen in above mentioned biomarkers from normal range, showed the toxicity of the compounds or molecules (Kuatsienu, Ansah, Adinortey, 2017). 
Toxicity assessment of the alcoholic leaves extract of Reinwardtia indica

TABLE III - Hematological parameters of rat treated with the different dose level of AERI in sub-acute toxicity after 14th day

\begin{tabular}{|c|c|c|c|c|c|c|c|c|}
\hline Parameter & Normal range & Control & $50 \mathrm{mg} / \mathrm{kg}$ & $250 \mathrm{mg} / \mathrm{kg}$ & $500 \mathrm{mg} / \mathrm{kg}$ & 1000 mg/kg & $2000 \mathrm{mg} / \mathrm{kg}$ & Satellite \\
\hline $\begin{array}{l}\text { Hemoglobin } \\
(\%)\end{array}$ & $10.2-46.6$ & $15.73 \pm 1.48$ & $14.11 \pm 1.08$ & $14.41 \pm 1.56$ & $13.65 \pm 0.39$ & $14.65 \pm 1.84$ & $13.59 \pm 1.21$ & $15.15 \pm 1.08$ \\
\hline $\mathrm{WBC}\left(10^{3} / \mu \mathrm{L}\right)$ & $6-15$ & $11.41 \pm 2.42$ & $9.08 \pm 2.96$ & $9.05 \pm 0.16$ & $10.68 \pm 1.32$ & $8.17 \pm 1.28$ & $9.29 \pm 1.50$ & $13.56 \pm 1.08$ \\
\hline $\operatorname{PVC}(\%)$ & $39-49$ & $48.05 \pm 1.23$ & $45.16 \pm 3.01$ & $44.58 \pm 2.05$ & $41.90 \pm 2.04$ & $42.13 \pm 2.02$ & $44.32 \pm 1.05$ & $48.89 \pm 1.14$ \\
\hline LC (\%) & $55-95$ & $71.09 \pm 1.52$ & $74.38 \pm 4.36$ & $72.24 \pm 1.06$ & $72.91 \pm 2.06$ & $77.78 \pm 1.98$ & $84.39 \pm 2.13$ & $93.03 \pm 1.23$ \\
\hline NP $(\%)$ & $10-40$ & $13.23 \pm 1.64$ & $14.48 \pm 3.60$ & $14.04 \pm 3.16$ & $60.41 \pm 1.14$ & $16.15 \pm 2.06$ & $23.58 \pm 2.16$ & $36.90 \pm 5.20$ \\
\hline MV (\%) & $1-4$ & $1.05 \pm 0.01$ & $1.28 \pm 0.25$ & $1.18 \pm 1.30$ & $1.38 \pm 0.28$ & $2.23 \pm 0.06$ & $1.82 \pm 0.18$ & $2.95 \pm 0.88$ \\
\hline
\end{tabular}

TABLE IV - Hematological parameters of rat treated with different dose level of AERI in sub-acute toxicity after 28th day

\begin{tabular}{|c|c|c|c|c|c|c|c|c|}
\hline Parameter & $\begin{array}{c}\text { Normal } \\
\text { range }\end{array}$ & Control & $50 \mathrm{mg} / \mathrm{kg}$ & $250 \mathrm{mg} / \mathrm{kg}$ & $500 \mathrm{mg} / \mathrm{kg}$ & $1000 \mathrm{mg} / \mathrm{kg}$ & $2000 \mathrm{mg} / \mathrm{kg}$ & Satellite \\
\hline Hemoglobin (\%) & $10.2-46.6$ & $16.02 \pm 1.91$ & $14.64 \pm 1.62$ & $15.60 \pm 0.79$ & $14.83 \pm 1.24$ & $15.84 \pm 1.72$ & $14.07 \pm 1.96$ & $15.15 \pm 1.08$ \\
\hline $\begin{array}{l}\text { Toat RBC } \\
\left(10^{6} / \mu \mathrm{L}\right)\end{array}$ & $5-10$ & $10.90 \pm 0.07$ & $9.88 \pm 0.45$ & $9.84 \pm 0.25$ & $9.93 \pm 0.05$ & $9.98 \pm 0.82$ & $9.54 \pm 0.65$ & $9.90 \pm 0.77$ \\
\hline $\operatorname{WBC}\left(10^{3} / \mu \mathrm{L}\right)$ & $6-15$ & $12.94 \pm 1.74$ & $9.85 \pm 0.69$ & $10.02 \pm 0.49$ & $1384 \pm 1.73$ & $11.63 \pm 0.49$ & $10.04 \pm 1.18$ & $13.56 \pm 1.08$ \\
\hline Platelets $\left(10^{3} / \mathrm{L}\right)$ & $782-985$ & $922.70 \pm 34.02$ & $959.17 \pm 63.22$ & $900.15 \pm 84.89$ & $885.11 \pm 49.56$ & $881.92 \pm 46.11$ & $977.56 \pm 70.56$ & $981.16 \pm 70.16$ \\
\hline PVC (\%) & $39-49$ & $49.9 \pm 2.16$ & $47.15 \pm 1.22$ & $46.50 \pm 2.14$ & $44.64 \pm 3.18$ & $45.07 \pm 1.09$ & $46.89 \pm 2.41$ & $48.89 \pm 1.41$ \\
\hline LC (\%) & $55-95$ & $76.10 \pm 3.68$ & $78.43 \pm 3.58$ & $73.59 \pm 2.15$ & $77.54 \pm 2.98$ & $89.98 \pm 2.17$ & $91.03 \pm 3.23$ & $93.03 \pm 1.23$ \\
\hline NP (\%) & $10-40$ & $25.32 \pm 1.88$ & $23.12 \pm 1.80$ & $28.50 \pm 1.10$ & $33.66 \pm 1.12$ & $13.34 \pm 2.89$ & $32.89 \pm 1.28$ & $369.90 \pm 5.20$ \\
\hline MV (\%) & $1-4$ & $1.50 \pm 0.15$ & $1.53 \pm 0.16$ & $1.48 \pm 0.12$ & $2.05 \pm 0.15$ & $2.36 \pm 0.12$ & $2.19 \pm 0.54$ & $2.95 \pm 0.88$ \\
\hline $\mathrm{EP}(\%)$ & $0-4$ & $1.93 \pm 0.11$ & $1.90 \pm 0.35$ & $1.94 \pm 0.38$ & $1.97 \pm 0.73$ & $2.80 \pm 0.61$ & $2.69 \pm 0.24$ & $2.90 \pm 0.84$ \\
\hline
\end{tabular}

The results suggested from our study that the levels or activities of biochemical parameters in animals after $14^{\text {th }}$ $\& 28^{\text {th }}$ days and found no significant variations occurred in SGOT, SGPT, ALP, Urea and creatinine levels at all tested doses in comparison to control. The satellite group after 6 weeks also showed the no significant changes in the above mentioned biochemical with compare to control (Table V and Table VI)

TABLE V - Biochemical estimation from blood serum of rats after 14th day's treatment at the different dose level in the subacute toxicity study

\begin{tabular}{|c|c|c|c|c|c|c|c|c|}
\hline Parameter & Normal range & Control & $50 \mathrm{mg} / \mathrm{kg}$ & $250 \mathrm{mg} / \mathrm{kg}$ & $500 \mathrm{mg} / \mathrm{kg}$ & $1000 \mathrm{mg} / \mathrm{kg}$ & $2000 \mathrm{mg} / \mathrm{kg}$ & Satellite \\
\hline$\overline{\mathrm{SGOT}(\mathrm{U} / \mathrm{L})}$ & $54-298$ & $153.6 \pm 16.70$ & $155.33 \pm 20.49$ & $163 \pm 33.34$ & $162.5 \pm 35.21$ & $163.33 \pm 33.59$ & $215.5 \pm 33.59$ & $99.02 \pm 3.09$ \\
\hline SGPT (U/L) & $17-77$ & $43.5 \pm 7.77$ & $43 \pm 9.9$ & $38.16 \pm 4.68$ & $49.16 \pm 6.06$ & $42 \pm 8.72$ & $51.16 \pm 7.72$ & $49.57 \pm 0.19$ \\
\hline $\begin{array}{l}\text { Creatinine } \\
(\mathrm{mg} / \mathrm{dL})\end{array}$ & $0.2-0.9$ & $0.34 \pm 0.035$ & $0.36 \pm 0.04$ & $0.34 \pm 0.04$ & $0.35 \pm 0.03$ & $0.35 \pm 0.02$ & $0.36 \pm 0.02$ & $0.28 \pm 0.026$ \\
\hline
\end{tabular}


TABLE VI - Biochemical estimation from blood serum of rats after 28th day's treatment at different dose level in sub- acute toxicity study

\begin{tabular}{lcccccccc}
\hline Parameter & Normal range & Control & $\mathbf{5 0} \mathbf{~} \mathbf{g} / \mathbf{k g}$ & $\mathbf{2 5 0} \mathbf{~} \mathbf{g} / \mathbf{k g}$ & $\mathbf{5 0 0} \mathbf{~} \mathbf{g} / \mathbf{k g}$ & $\mathbf{1 0 0 0} \mathbf{~} \mathbf{g} / \mathbf{k g}$ & $\mathbf{2 0 0 0} \mathbf{~ m g / k g}$ & Satellite \\
\hline SGOT (U/L) & $54-298$ & $163.5 \pm 32.5$ & $167.16 \pm 32.74$ & $183.33 \pm 24.8$ & $178.66 \pm 19.2$ & $192.5 \pm 35.47$ & $208.66 \pm 15.99$ & $99.02 \pm 3.09$ \\
SGPT (U/L) & $17-77$ & $45.5 \pm 8.65$ & $46 \pm 7.94$ & $39.83 \pm 6.19$ & $59.33 \pm 6.15$ & $46.66 \pm 7.27$ & $53.5 \pm 7.18$ & $49.57 \pm 0.19$ \\
ALP (U/L) & $64-128$ & $95.33 \pm 6.71$ & $101 \pm 7.5$ & $97.66 \pm 9.13$ & $106.16 \pm 5.59$ & $99.5 \pm 3.39$ & $111.16 \pm 9.3$ & $103.97 \pm 3.18$ \\
Creatinine & $0.2-0.9$ & $0.39 \pm 0.05$ & $0.38 \pm 0.023$ & $0.47 \pm 0.05$ & $0.8 \pm 0.04$ & $0.44 \pm 0.05$ & $0.45 \pm 0.02$ & $0.28 \pm 0.026$ \\
(mg/dL) & & & & & & & & \\
Urea (U/L) & $35-96$ & $65.16 \pm 5.66$ & $68.66 \pm 8.61$ & $66.83 \pm 6.71$ & $81 \pm 6.22$ & $61.66 \pm 6.09$ & $65.66 \pm 8.85$ & $43 \pm 5.41$ \\
BUN (mg/dL) & $8-33$ & $30.43 \pm 2.64$ & $37.82 \pm 2.9$ & $32.21 \pm 3.13$ & $35.49 \pm 2.69$ & $28.79 \pm 2.84$ & $30.66 \pm 4.13$ & $20.08 \pm 2.47$ \\
\hline
\end{tabular}

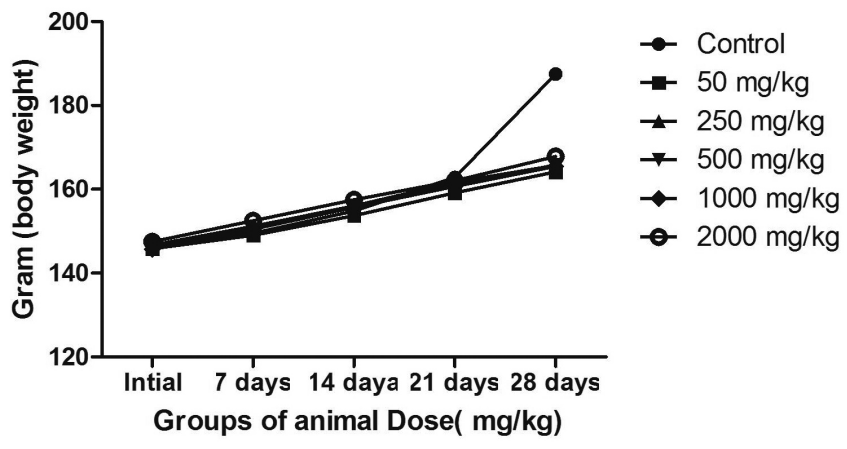

FIGURE 1 - Body weight assessment of treated rats in sub-acute toxicity study.

\section{Histopathology}

In the histopathological study, we found that in all treated groups after 14 days (Figure 2) and 28 days (Figure 3) the organs showed no changes at cellular level in comparison to control. The histopathology slides also confirmed the AERI treated group up to the dose of $2000 \mathrm{mg} / \mathrm{kg}$ showed no toxicity in 4 weeks.

\section{Estimated dose}

The $1 / 10$ th and $1 / 20$ th of maximum dose from
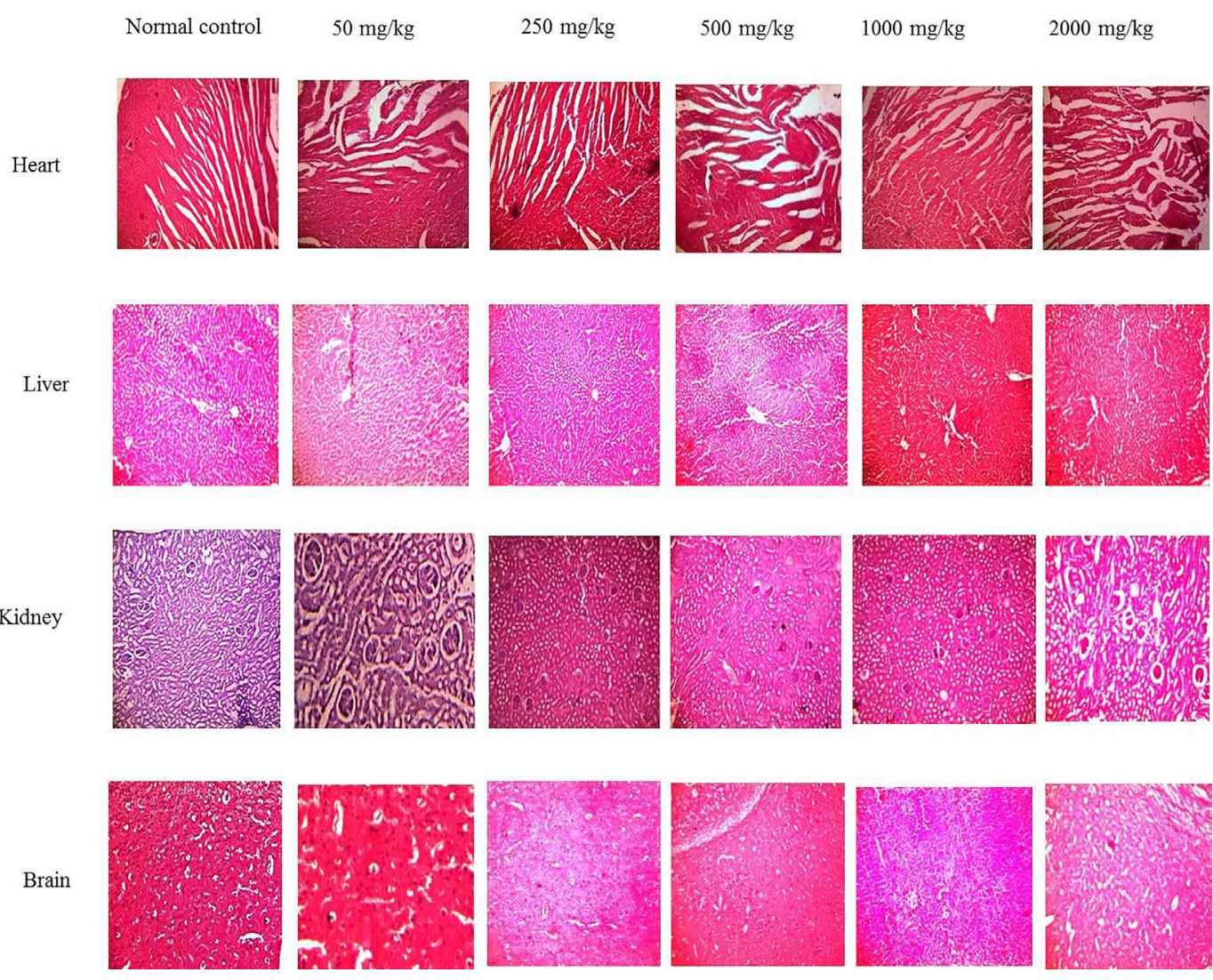

FIGURE 2 - Histopathology (H\&E stain10x) of rat tissues of treated groups rats after 14th days. 

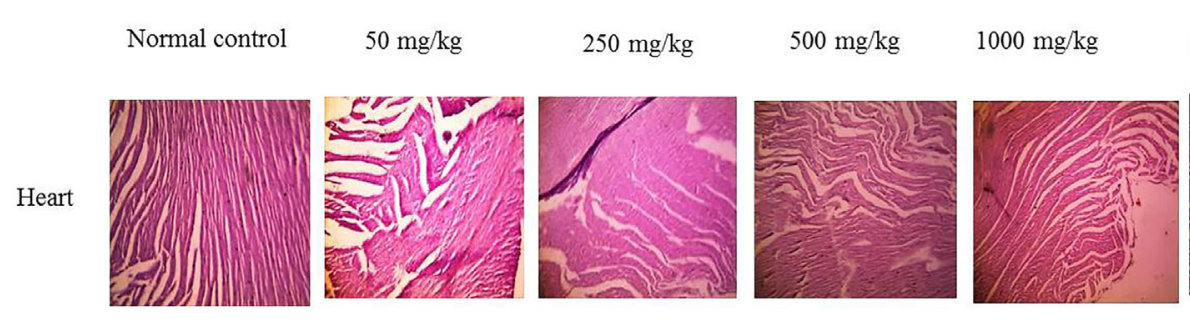

$2000 \mathrm{mg} / \mathrm{kg}$
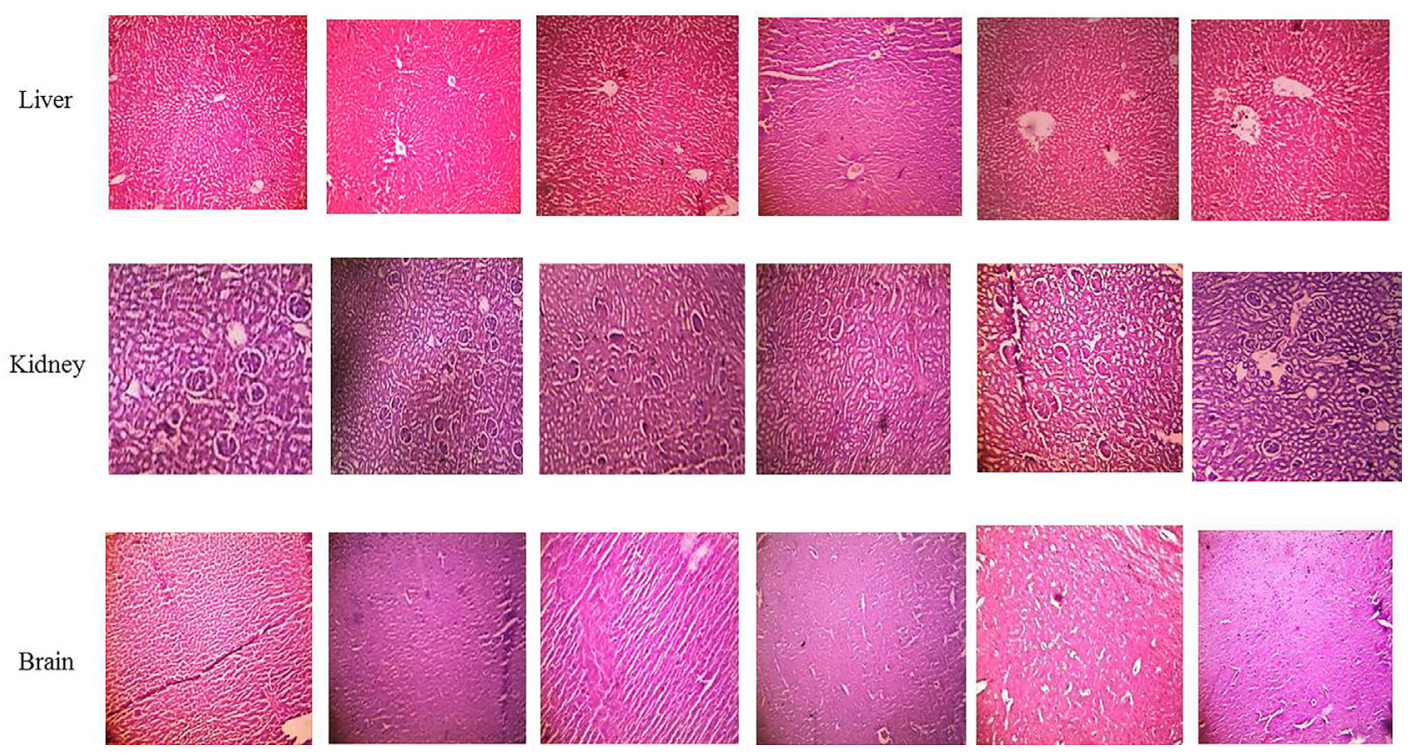

FIGURE 3 - Histopathology (H\&E stain10x) of rat tissues of treated groups rats after 28th days.

toxicity assessment study were taken and the estimated dose for animal would be 500 and $250 \mathrm{mg} / \mathrm{kg}$. The human equivalent dose from 500 and $250 \mathrm{mg} / \mathrm{kg}$ body wt. dose of animal would be $81.08 \mathrm{mg} / \mathrm{kg}$ and $40.54 \mathrm{mg} /$ $\mathrm{kg}$. Considering average human body wt. of $60 \mathrm{~kg}$, the estimated daily dose would be $4.801 \mathrm{gm} /$ day. The data may be helpful for further study of this extract on animal. The estimated human daily dose may be used for clinical study of the extract.

\section{CONCLUSIONS}

The oral dose of maximum $5000 \mathrm{mg} / \mathrm{kg}$ of the alcoholic extract of leaves Reinwardtia indica showed no treatment-related signs of toxicity or mortality. In the repeated dose for 28-day, the oral administration at the different dose level of AERI up to $2000 \mathrm{mg} / \mathrm{kg}$ showed no significant changes in intake of food \& water, haematology, biochemical serum analysis and histopathology at the cellular level. It is clearly indicated that the AERI can be used for further evaluation of pharmacological activities on the above mentioned dose of extract.

\section{ACKNOWLEDGEMENT}

We have to express our appreciation to the late Dr. Suresh Purohit, professor, department of pharmacology for sharing his pearls of wisdom with us during the course of this research.

\section{REFERENCES}

Abha S, Swati V, Shukla RK. Preliminary phytochemical screening, antibacterial and nitric oxide radical scavenging activities of Rinwardtia indica leaves extract. Int J PharmTech Res. 2013;5(4):1670-1678.

Bhat JA, Kumar M, Bussmann RW. Ecological status and traditional knowledge of medicinal plants in Kedarnath Wildlife Sanctuary of Garhwal Himalaya, India. J Ethnobiol Ethnomed. 2013;9:1-18.

Cn A. Lily and black potato flour and preparation method thereof. Publication date: CN 103876032 A; 2014a. p. 8-10. https://patents.google.com/patent/CN103876032A/ en?oq $=\mathrm{CN}+103876032+$. 
Cn A. Traditional Chinese medicine for treating acute or chronic gastritis.CN 103705734A; 2014b. p. 14-15. https://patents. google.com/patent/CN103705734A/en?oq=CN+103705734A.

Khan SA, Ibrar M, Shukla A, Vats S, Shukla RK, Painuly D, Porval A, Tyagi R, Sonam M, Singh RP, Pooja S. Linaceae. Int J Pharmacogn Phytochem Res. 1998;39:34-38.

Koumba Madingou NO, Traore A, Souza A, Boukandou Mounanga MM, Aworet Samseny RR, Ouedraogo S, Sababenedyo Traore A. Preliminary studies of acute and subchronic toxicity of the aqueous extract of Guibourtia tessmannii (Harms) J. Leonard stem barks (Caesalpiniaceae) in mice and rats. Asian Pac J Trop Biomed. 2016;6(6):506-510.

Kuatsienu LE, Ansah C, Adinortey MB. Toxicological evaluation and protective effect of ethanolic leaf extract of Launaea taraxacifolia on gentamicin induced rat kidney injury. Asian Pac J Trop Biomed. 2017;7(7):640-646.

Malla B, Gauchan DP, Chhetri RB. Medico-ethnobotanical investigations in Parbat district of Western Nepal. J Med Plants Res. 2014;8(2):95-108.

Pande P, Tiwari L, Pande H. Indian journal of traditional knowledge. Indian J Tradit Know. 2007;6:444-458.

Parasuraman S. Toxicological screening. J Pharmacol Pharmacother. 2011;2(2):74-9.

Paudel Chhetri H, Shrestha Yogol N, Sherchan J, Mansoor S. Phytochemical and Antimicrobial evaluations of some medicinal plants of Nepal. Kathmandu. Kathmandu Univ J Sci Eng Technol. 2008;4(1):49-54.
Perveen A, Qaiser M. Pollen flora of Pakistan-lix. Linaceae. Pak J Bot. 2008;40(5):1819-1822.

Quanru L, Zhou L. Linaceae 亚麻科 ya ma ke. 1998;39:34-38.

Rawat A, Singh Rana P, Molpa D, Saklani P. Phytochemical composition and antioxidant activity of Reinwardtia indica from selected location of Uttrakhand. Int JProresses Eng Manag Sci Humanit. 2015;1(3):59-67.

Saleem M, Ja Kim H, Shaiq Ali M, Sup Lee Y. An update on bioactive plant lignans. NatProdRep. 2005;22(6):696-716.

Sidhu MC, Thakur S. Phytochemical and elemental exploration of nothoscordum gracile (Aiton) stearn for its medicinal potential. J Chem Pharm Sci. 2016;9(4):2627-2631.

Uddin N, Hasan MR, Hasan MM, Hossain MM, Alam MR, Hasan MR, Islam AFMM, Rahman T, Rana MS. Assessment of toxic effects of the methanol extract of Citrus macroptera Montr. Fruit via Biochemical and hematological evaluation in female Sprague-Dawley rats. PLoS One. 2014;9(11):e111101.

Zhang D, Luo G, Ding X, Lu C. Preclinical experimental models of drug metabolism and disposition in drug discovery and development. Acta Pharm Sin B. 2012;2(6):549-561.

Received for publication on $07^{\text {th }}$ May 2018 Accepted for publication on $12^{\text {th }}$ June 2018 